\title{
Guide to
}

Sustainable Development

and Environmental

Policy 



\title{
Guide to
}

\section{Sustainable Development}

\section{and Environmental}

\author{
Policy
}

\author{
EDITED BY \\ NATALIA MIROVITSKAYA \\ AND WILLIAM ASCHER
}


(C) 200I Duke University Press

All rights reserved

Printed in the United States of America on acid-free paper @ Library of Congress Cataloging-in-Publication Data appear on the last printed page of this book. 